\title{
CHANGES IN ACCESSIBILITY IN EASTERN EUROPE DUE TO THE ROAD INVESTMENTS ALONG THE VIA CARPATIA CORRIDOR
}

\begin{abstract}
The main objective of the article is to assess the potential impact of the completed Via Carpatia route on changes in the accessibility of regions on a European scale. The model of potential accessibility in the international approach was used (sources and destinations at the NUTS3 level). The accessibility analysis showed that the range of impact of the investment is extensive and extends from the north of the continent to central Turkey, and the effectiveness of construction of individual sections is strongly dependent on the simultaneous investment in neighboring countries.
\end{abstract}

Keywords: Via Carpatia corridor, road investments, TEN-T road network, potential accessibility

\section{Introduction}

The aim of the functioning and development of the TEN-T network is to ensure territorial cohesion of the EU, improve the free transport of people and freight, and consequently -improve the functioning of the single internal market, stimulate economic growth, and improve the competitiveness of Member States and the entire EU on a global scale. Creation of a coherent and interoperable, multimodal transport network with unified, high technical parameters is possible only in the case of full coverage by the entire European Union network. This also applies to areas located near the eastern border of the EU. During the previous (2007-2013) and current 
(2014-2020) financial perspective, these areas have significantly improved their accessibility as a result of the implementation of latitudinal investments linking them with the core areas of individual countries as well as the entire Union. However, at the same time there is still a lack of a southern communication axis that could favor the development of peripheral areas, and at the same time play an integration role towards the Western Balkans, Eastern Partnership countries as well as Turkey and the Middle East. An initiative that can fill this gap is the postulated way of Via Carpatia (along with branches).

It is assumed that changes in accessibility will be one of the main effects of investment activities in the Via Carpatia corridor. The corridor runs through peripheral areas, which have been characterized by a relatively lower level of accessibility (both on the EU scale and within the Member States). This means that the development effect of this improvement can be significant, including for undertaking investment activities by potential investors, which should be encouraged by modern road infrastructure. The correct quantification of the expected effects of Via Carpatia at the European level is extremely important. They allow for an objective assessment of the legitimacy and then the preparation of future investment projects, including their proper stages.

The article presents a forecast concerning changes in the transport accessibility of regions through which the basic route of Via Carpatia will run, in the European system, taking into account changes resulting from the implementation of investments on particular sections of the route.

The main goal of the article is to assess the potential impact of the completed Via Carpatia route on changes in the region's accessibility. The spatial scope of the study (both sources and destinations) covered the entire geographical Europe (including the countries of the former Soviet Union, including the European part of Russia), as well as Turkey. Such a large territorial range distinguishes the analysis from many previous European accessibility studies ${ }^{1}$. The applied approach allows also to assess the effects of investments on both sides of the external EU border, and thus to identify the reducing impact of this border, understood as a formalized spatial barrier ${ }^{2}$. The time horizon of the survey goes back 10 years from the planned completion of the Polish part of the investment (i.e. 2025-2035). Thus, the analysis, including the forecasts of changes in accessibility, are made in the long-term perspective, i.e. until 2035. It is a perspective in which the creation of the whole rout can be considered real.

The accessibility analysis was carried out first for the whole of Europe to indicate what the overall level of accessibility of the regions along the Via Carpatia route is. Then, the accessibility changes for the entire Via Carpatia route were simulated. The authors analyzed the expected shortening of travel time between the complete 1585 transport regions in Europe, as a result of bringing the Via Carpatia route

1 Transport services and networks: territorial trends and basic supply of infrastructure for territorial cohesion. Final Report, ESPON 1.2.1, 2014; K. Spiekermann et al., TRACC Transport Accessibility at Regional/Local Scale and Patterns in Europe. Final Report, ESPON Applied Research 2014.

2 Z. Rykiel, Koncepcje granic w badaniach geograficznych, Geographic Journal 1990, 62, p. 263-273 and T. Komornicki, Granice Polski. Analiza zmian przenikalności w latach 1990-1996, Geopolitical Studies 1999,5, p. 348. 
to a level equivalent to that expected for the TEN-T network corridor, which means at least a level equal to the expressway (in places where a change of category is planned on the highway). So-called net effect of improving accessibility as a result of implementation of Via Carpatii was examined, i.e. assuming ceteris paribus - other unchanged factors. The article is the result of theoretical research carried out under the own grant financed by The National Science Centre (Poland) No. UMO-2014/13/B/HS4/03397.

\section{Via Carpatia route}

The initiative to build a road called Via Carpatia was undertaken for the first time at an international conference organized in Łańcut in 2006. Its initiators were Poland, Lithuania, Slovakia and Hungary. The transport ministers of these countries then signed a declaration of joint efforts to enter the trail into the TEN-T network. In 2010, it was supported by other countries (Bulgaria, Romania and Greece).

The planned main route of Via Carpatia, according to the so-called The Eańcut Declaration (2016) runs from Klaipeda and Kaunas in Lithuania through Białystok, Lublin and Rzeszów in Poland, Slovak Prešov and Košice to Miskolc and Debrecen in Hungary and further to Romania, where the main route Via Carpatia runs from Oradea, through Arad and Timisoara in the direction of Bulgaria (Sofia) and Greek ports (Thessaloniki, Alexandropolis) and then further to Turkey, to Istanbul (Figure 1). The Via Carpatia "arms" lead from the Polish Baltic ports to south-eastern Poland, joining with subsequent ones leading to Ukraine Lublin with Kowel and Lublin and Rzeszów with Lviv. In Ukraine, the arms run from the western part of the country towards Kiev and further to the port of Odessa. In Ternopil, the route also branches towards Romanian Galati and Bucharest. In addition, in Romania, the route branches off in Oradea and Lugoj towards the port of Constanta. In Bulgaria, the route leads from Sofia to the border with Turkey, and then to Istanbul.

It is worth noting that the Polish Ministry of Infrastructure has taken the initiative to include the Via Carpatia corridor into the TEN-T core network along the entire course of the next TEN-T network update. According to art. 54 By Regulation (EU) No 1315/2013 of the European Parliament and of the Council of 11 December 2013 on EU guidelines for the development of the trans-European transport network, the European Commission should review the implementation and possible updating of the core network by 31 December 2023. 


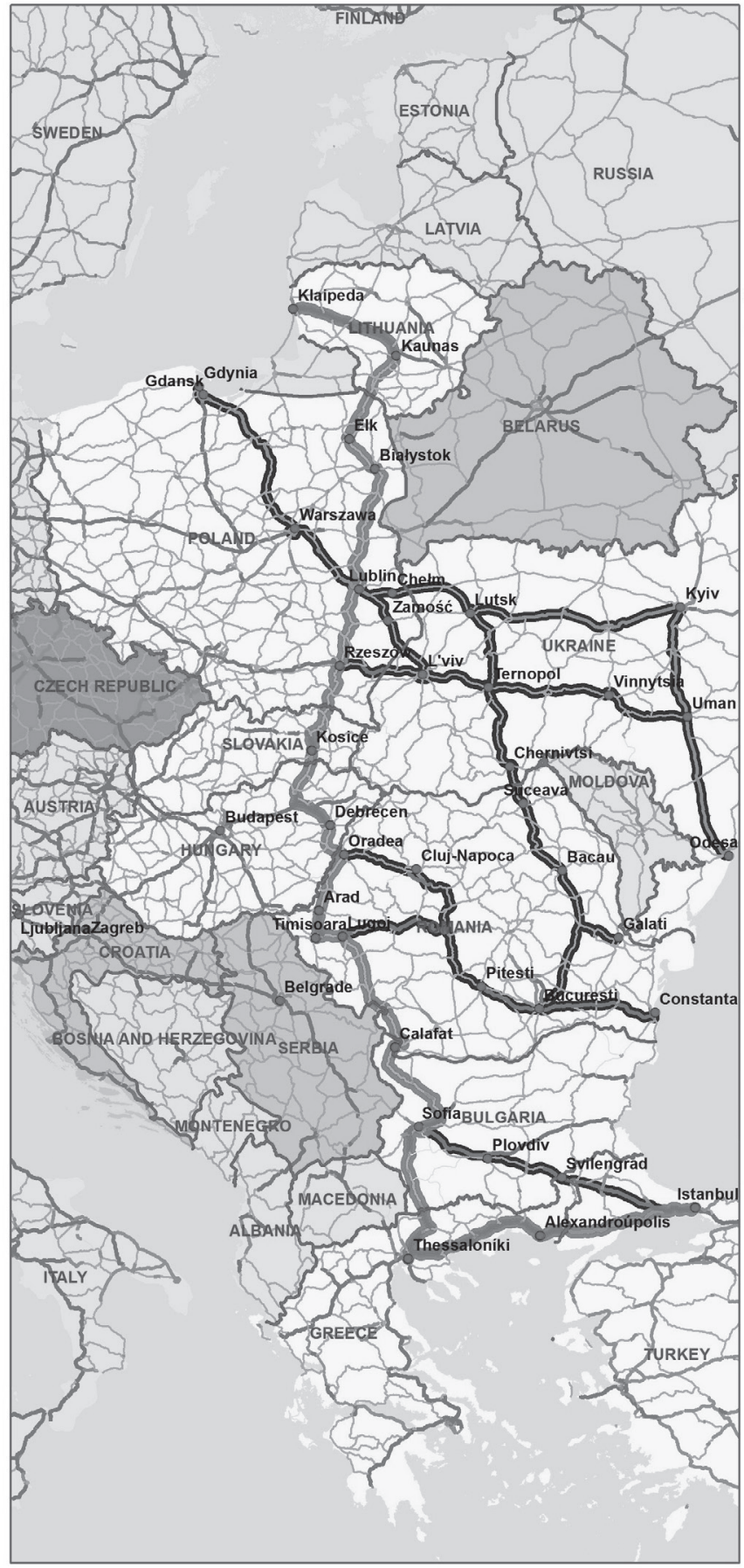

VIA CARPATIA TRANSPORT CORRIDOR ACCORDING TO THE ŁAŃCUT II DECLARATION Countries:

\section{Observe \\ Corridors: Main Route Roads: \\ Motorway - Expressway - Main Cities: - Main cities}

States situated along the Via Carpatia route Interested States Via Carpatia route: Lithuania - overall $341 \mathrm{~km}$ : Klaipeda - Kaunas - $245 \mathrm{~km}$ Kaunas - LT/PL border - $96 \mathrm{~km}$ Poland - overall $1533 \mathrm{~km}$ :

LT/PL border - Białystok - $180 \mathrm{~km}$ Białystok - Lublin - $249 \mathrm{~km}$ - Lublin - Rzeszow - $167 \mathrm{~km}$ Rzoszow - PL/SK border - $88 \mathrm{~km}$ Gdansk - Lublin - $507 \mathrm{~km}$ Lublin - $L$ LA A Rzeszów - PL/UA border - $97 \mathrm{~km}$ Slovakia - overall $135 \mathrm{~km}$ :

- PL/SK border - Kosice - $107 \mathrm{~km}$ - Kosice - SK/HU border - $28 \mathrm{~km}$ Hungary - overall 240 km - SK/HU border - Miszkolc - $65 \mathrm{~km}$ - Miszkolc - Debrecen - $110 \mathrm{~km}$ - Mebrecen - HU/RO border - $65 \mathrm{~km}$ Romania - overall $1851 \mathrm{~km}$ :

- Bors - Oradea - Arad -Timisoara - Lugoi Calafat (RO/BG border) $-462 \mathrm{~km}$

- Lugoi - Sibiu - Pitesti - Bucaresti Constanta - $732 \mathrm{~km}$

Seret - Suceava - Bacau - Bucaresti $468 \mathrm{~km}$

- Bacau - Galati - $189 \mathrm{~km}$ Bulgaria - overall $662 \mathrm{~km}$ - RO/BG border - Sofia - Kuluta (BG/GR border) - $380 \mathrm{~km}$ - Sofia - Plovdiv - Svilengra (BG/TR border) - $282 \mathrm{~km}$ Greece - overall $452 \mathrm{~km}$ : BG/GR border - Thessaloniki - $114 \mathrm{~km}$ Thessaloniki - GR/TR border - $338 \mathrm{~km}$ Ukraine - overall $2005 \mathrm{~km}$ PL/UA border - Kovel - $66 \mathrm{~km}$ Kovel - Lutsk - $74 \mathrm{~km}$ Lutsk - Kiev - $402 \mathrm{~km}$ - Kiev - Odessa - $477 \mathrm{~km}$
- Lutsk - Ternopil - $167 \mathrm{~km}$ - Ternopil - Chernivtsi - UA/RO border $212 \mathrm{~km}$ PL/UA border - Lviv -Ternopil - $200 \mathrm{~km}$ -Ternopil - Vinnitsa - Uman - $407 \mathrm{~km}$ Turkey - overall $507 \mathrm{~km}$

GR/TR border - Istanbul - $254 \mathrm{~km}$ BG/TR border - Istanbul - $243 \mathrm{~km}$

$\begin{array}{lll}75 \quad 150 \quad 300 \mathrm{~km} & 0\end{array}$

Figure 1. Via Carpatia - route diagram

Source: own elaboration based on materials from the Ministry of Infrastructure 
Connections of Via Carpatia corridor with other road corridors within core network TEN-T are as follows (the names of the towns/cities are indicative only, actual courses vary in relation to the location of the town/city, relevant junctions are provided in the description of the network status in individual countries):

1) North Sea - Baltic TEN-T corridor. Klaipeda-Elk;

2) Outside TEN-T, Ełk-Knyszyn;

3) Comprehensive network TEN-T, Knyszyn-Lublin;

4) Core network TEN-T, Lublin-Rzeszow;

5) Comprehensive network TEN-T, Rzeszow-Prešov;

6) Rhine-Danube TEN-T corridor, Prešov-Košice;

7) Comprehensive network TEN-T, Košice-Miskolc;

8) Mediterranean TEN-T corridor, Miskolc-Debrecen;

9) Comprehensive network TEN-T, Debrecen-Arad;

10) Rhine-Danube TEN-T corridor and Orient-East Med TEN-T corridor, AradDrobeta-Turnu Severin;

11) Outside TEN-T, Drobeta-Turnu Severin-Calafat/Vidin;

12) Orient-East Med TEN-T corridor, Calafat-Vidin-Thessaloniki;

13) Core network TEN-T, Thessaloniki-Ipsala;

14) Outside TEN-T, Ipsala-Istanbul.

The overall state of the Via Carpatia corridor can be briefly described as follows. Currently, i.e. at the end of 2017, the Via Carpatia is only partially ready; indicatively, the following sections are in existence:

- Lithuania, Klaipeda-Kaunas;

- Poland, short sections in the area of Suwałki, Lublin and Rzeszów;

- Slovakia, almost the whole section Prešov-Košice-border with Hungary;

- Hungary, Miskolc-Debrecen;

- Romania, Arad-Lugoj;

- Bulgaria, Botevgrad-Sofia-Blagoevgrad;

- Greece, almost the whole course;

- Turkey, built in the dual carriageway standard, although not meeting the requirements for expressways on the western section. No further actions needed, except for road renovations.

Realistically, it is very likely that by 2023 sections that are at least at the stage of tender at the end of 2017 will have been delivered the following sections:

- Lithuania, almost the whole Lithuanian section to the border with Poland;

- Poland, aections Suwalki-Elk and Lublin-Rzeszow;

- Slovakia, completion of the missing sections between Prešov and the border with Hungary;

- Hungary, completion of the missing sections on all the course of the route;

- Romania; no significant activities, except for the short section on the border with Hungary;

- Bulgaria, no significant activities, except for the short missing section between Sofia and the border with Greece;

- Greece, completion of the missing section. 


\section{Research methodology}

Accessibility can be measured using a number of methods, from which the so-called potential accessibility was chosen ${ }^{3}$. This method allows simulation of changes in accessibility in spatial terms as a result of putting any part for use (e.g. a new part of an expressway or raising the road category on a given section), or a group of sections or the entire program, e.g. CEF. The most important distinction of potential accessibility is that the attractiveness of the travel/carriage purpose increases with its size and decreases as the physical, temporal or economic distance increases (in the case of this study it is travel time). As an attraction (destination) the population in the transport region from 2015 was taken into account. A model built for the whole of the European continent at the NUTS3 level (area of the European Union) was used. Outside the European Union, the rest of European countries were divided according to the administrative division (for example, Ukraine, Belarus and Russia are divided into so-called oblasts, and in NUTS units in Turkey and some other countries based on Eurostat data). In total, 1585 transport regions were distinguished. Thus, it is the first European accessibility model functioning in Poland.

The road network for the whole continent has been developed by adapting the Open Street foundation for the model, dividing the network into five categories of roads: motorways, expressways, dual carriageways, single-station national roads, other roads of regional and local importance. The code speeds applicable in a given country were adopted, while reducing the speed for regional and local roads. The waiting times at borders were also taken into account. All the capitals of the regions (relatively largest cities in the transport regions connected with the network, when the capital of the region was much smaller than the largest city) were connected. The OGAM application developed at the Institute of Geography and Spatial Organization of the Polish Academy of Sciences was used to simulate potential accessibility. The model always performs simulation on all the shortest travel routes between any pair of transport regions.

Formula was used for so-called potential accessibility. In the described study, the formula takes the form:

$$
A_{i}=M_{i} f\left(t_{i i}\right)+\sum_{j} M_{j} f\left(t_{i j}\right)+\sum_{k} M_{k} f\left(t_{i k}\right)+\sum_{l} M_{l} f\left(t_{i i}\right),
$$

where:

$M_{i} f\left(t_{i i}\right)$ - the own potential of the NUTS3 region and $\left(t_{i i}\right)$ inter-regional journey time $e^{4}$.

The sum of own potential and the second component $\Sigma_{i} M_{j} f\left(t_{i j}\right)$ is the domestic potential where $\left(t_{i j}\right)$ is the travel time between any pair of NUTS3 regions and $\mathrm{j}$ within a given country. The sum of the domestic potential and the third component $\Sigma_{k} M_{k} f\left(t_{i k}\right)$ is the international potential of the Schengen area where $\left(t_{i k}\right)$

P. Rosik, Dostępność lądowa przestrzeni Polski w wymiarze europejskim, Geographic Journal 2012, 231, p. 310.

4 D.C. Rich, Population potential, potential transportation cost and industrial location, Area, 1978, p. 222-226;

J. Gutiérrez, Location, economic potential and daily accessibility: analysis of the accessibility impact of the high-speed line Madrid-Barcelona-French border, Journal of Transport Geography2001, 9, p. 229-242. 
is the travel time between two transport regions NUTS3 and k located in different countries belonging to the Schengen area. Ultimately, the sum of the potential of the Schengen area and the fourth component $\Sigma_{l} M_{l} f\left(t_{i l}\right)$ is an international potential on a European scale where $\left(t_{i l}\right)$ is travel time taking into account waiting time at borders, Schengen area and other borders on the European continent.

In the case of The resistance of the space, describing the speed of decline in the attractiveness of the destination along with the longer travel time, used the exponential function (exponent) which is related to the appropriate selection of the parameter $\beta$ in the function of space resistance $f(c i j)=\exp (-\beta \mathrm{t})$. The appropriate parameter $\beta$ is indicated in the function of space resistance, the selected indicator $\beta=0.005775$, for which the attractiveness of the destination is half at two hours of travel, and $10 \%$ at about 400 minutes (6 hours and 40 minutes) $)^{5}$.

\section{The analysis of changes in accessibility as a result of implementation of the entire Via Carpatia route}

The results of the study indicate that the continental distribution of accessibility is to a large extent "based" on the European core (Figure 2). The Ruhr region has the highest level of this indicator. Along with moving away from the European core, access is falling in all directions, but the rate of this decline depends to a large extent on the density of population and the condition of road infrastructure. In Poland, for example, access is falling from the south-west towards the north-east, but it remains at a higher level (more than 40 units) along the A2 (to Warsaw) and A4 (to Kraków and Tarnów) highways. The enclaves of higher accessibility in the peripheral areas of Eastern Europe are primarily Moscow and Istanbul, and to a lesser extent St. Petersburg.

The area along the Via Carpatia route is characterized by a rather low level of accessibility on the European scale, from very low values in Lithuania and northern Greece, to relatively higher ones in the vicinity of Istanbul and in the central part of the corridor (from Lublin to Timisoara), again with the "peak" in Rzeszów (Figure 3).The better accessibility of the Polish, Slovak and Hungarian sections depends on the geographical location of the EU core area and better developed latitudinal infrastructure. The Via Carpatia is in this case an important role connecting the areas between the East-West highways (Polish A4, Slovak D1, Hungarian M3) to these routes. The improvement of the accessibility indicator can therefore take place as a result of the cumulative effect of Via Carpatia and latitudinal highways, proving that the meridional system cannot be seen as an alternative to the latitudinal one. They are completing in improving the accessibility of the eastern borderland of the European Union. In this context, it is advisable that Via Carpatia be supplemented with routes perpendicular to it, such as the eastern section of the Polish A2 highway.

5 M. Stępniak, P. Rosik, Accessibility improvement, territorial cohesion and spillovers: a multidimensional evaluation of two motorway sections in Poland, Journal of Transport Geography 2013, 31, p. 154-163. 


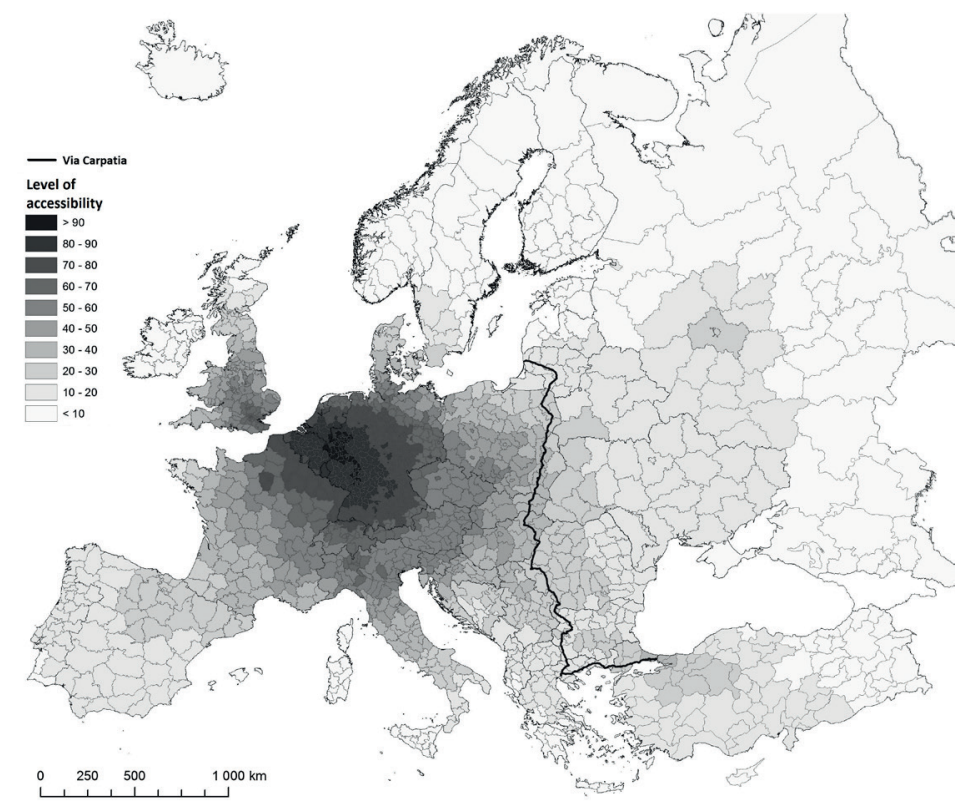

Figure 2. Road accessibility in 2013

Source: own elaboration using the potential model and speed model of IGiPZ PAN

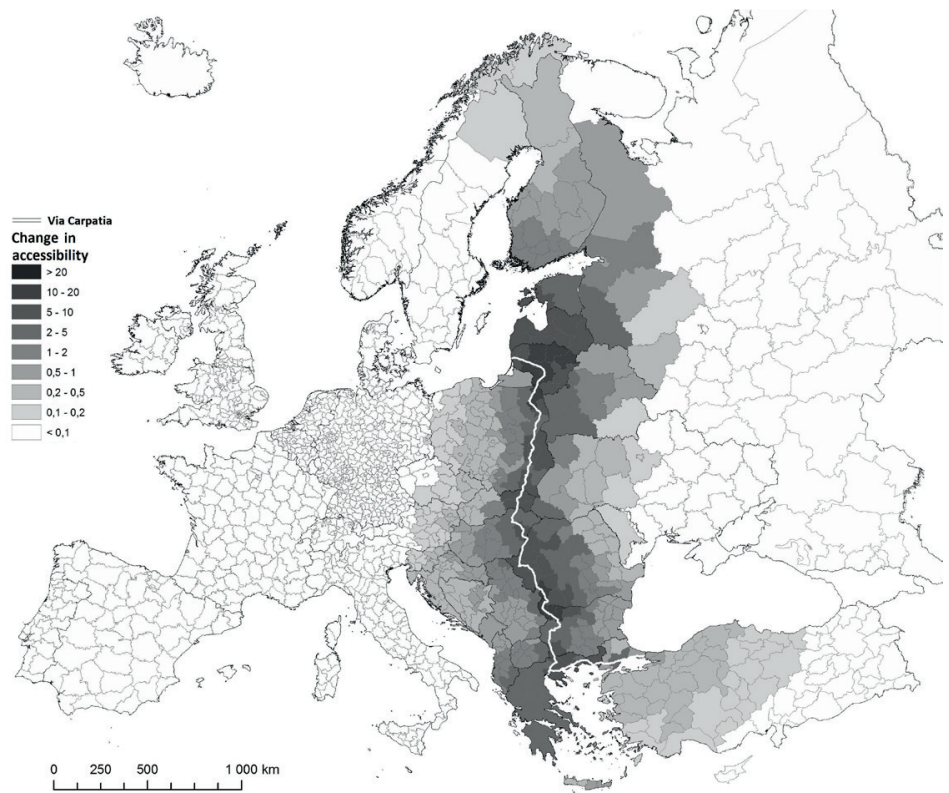

Figure 3. Change of road accessibility to the population as a result of implementation of the Via Carpatia investment

Source: own elaboration using the potential model and speed model of IGiPZ PAN 
The accessilibity analysis showed that the range of impact of the investment is extensive and extends from the north of the continent (northern Finland, and even Sweden and Norway) to central Turkey. On the western side, the improvement of accessibility above $0.1 \%$ is visible more or less east of the Polish-German border to Slovenia. The largest beneficiaries of the investment are, like in the short journeys, the Bulgarian-Romanian and Polish-Lithuanian borders (improvement in Kaunas by $14.3 \%$ ), but the large effects of improving accessibility (over 5\%) are also visible in Latvia, Greece and in principle in all the countries along the corridor have regions where accessibility increases above $5 \%$. The smallest effects are for obvious reasons along those sections that already at the end of 2015 had the status of an expressway or highway, and no further investments are planned there (Miskolc, Sofia, Istanbul, Thessaloniki).

It is worth noticing that there is the significant improvement of accessibility in some countries outside the European Union. This applies to what is interesting, to a greater extent Belarus and northern Russia (the area of St. Petersburg) rather than Ukraine. Physical remoteness means that the new investment improves accessibility in northern Russia and in Finland. In the case of Ukraine, which is closer to the core of the European Union, the effect is not so large as to offset the losses resulting from the infrequently penetrating border. The beneficiaries of the route in a natural way are also Western Balkans, in particular Serbia (in Vojvodina, a growth of 5\%) and Macedonia. However, the benefits of the order of $0.5-1 \%$ go back to the Adriatic coast (in Albania). Generally, the countries located west of Via Carpatia (through which the route does not run) benefit all the countries of the former Yugoslavia, Albania, as well as Austria and the Czech Republic. The analysis of potential accessibility provides arguments for increasing the number of countries involved for Serbia, and second for Macedonia and Albania.

Expectations of individual countries and regions in relation to Via Carpatia can be naturally different. In the peripheral areas (north and south end of the corridor, but also its branches to the east - Ukraine), they are associated with better communication with Central Europe and indirectly Western Europe. In the central part of the corridor the justification of building the corridor one should look for in acceleration of economic development through better use of additional endogenous potentials (less dependent on connections with the western part of the Union).

\section{Conclusions}

Accessibility should be understood as the existence (creation) of an opportunity for social and economic development in the regional and local dimensions. It is a measure of the extent to which the transport network fulfills the condition necessary for development. From this point of view, the eastern peripheries of the European Union remain, in a large part, an area with development opportunities reduced by the underdevelopment of transport infrastructure, expressed by lower spatial accessibility indicators. The analysis confirmed that the construction of the Via Carpatia route can improve this situation. However, the possible positive investment result is selective in the territorial sense. It is also dependent on other 
investments, including routes with latitudinal and oblique runs. It is not an alternative to them, only a complementary one. As a rokad route connecting peripheral areas, it is a "second-line" investment in respect of routes linking the periphery to core (national and European) areas. Most of these trails have already been established or are being implemented (especially in Poland in Slovakia and Hungary). In this context, taking the initiative to build the Via Carpatia road is now justified.

The above-mentioned selectivity of the obtained effects is clearly visible at the level of individual cities along the Via Carpatia route. The improvement of accessibility is of particular importance for medium-sized cities located in the northern and central part of the route (e.g. Lublin, Rzeszów, Kowno, Košice). They are characterized by a relatively weak own potential and good initial accessibility (geographic proximity of the core of the European Union and the existence of new latitudinal road routes). The new route may be an additional development impulse for them, resulting not only from the connection on the north-south axis, but also from better communication with their own facilities. Earlier research results on the impact of transport infrastructure improvement on development indicate that it concentrates rather in metropolitan centers and large cities and remains problematic in the periphery and rural areas ${ }^{6}$. On the other hand, in already large metropolises already formed (in the analyzed case they are Istanbul and to some extent also Sofia), the effect of the new road investment, measured by the improvement of the potential accessibility, is moderate. This leads to the conclusion that the main beneficiaries of the route may be those medium-sized cities, which are potential growth poles of the eastern periphery of the EU. The conducted study indirectly also showed the importance of cross-border cooperation in coordinating road investments. The efficiency of the construction of individual sections is strongly dependent on the simultaneous investment in both neighboring countries (e.g. on the Polish-Slovakian border).

It is important to conclude that the Via Carpatia route is potentially beneficial not only for the members of the European Union, but also for the so-called neighborhood of the Union. It reaches Istanbul - the largest city of Turkey and its arms are located in Ukraine. The countries concerned are (apart from Turkey and Ukraine) - Serbia and Bosnia and Herzegovina, as well as an EU member - Croatia. In the immediate vicinity of the route there are Macedonia and Belarus. Moldova is also located between the arms of the route in Romania and Ukraine. In the described system, Via Carpatia is an opportunity for the development of many regions located in the East of the European Union, not only as a single route, but also as the axis of the transport system serving the eastern borderland of the entire EU. Via Carpatia will also have a significant contribution to integrating EU and neighboring countries, especially Ukraine and Turkey. The trail contains the earlier concepts of transport corridors (such as the idea of Via Intermare). Long-term Via Carpatia will be conducive to the intensification of trade and investment links in the north-south direction, as a complement to the latitudinal system dominating in the EU.

The study clearly revealed the negative impact of a highly formalized border (the eastern border of the EU and the Schengen area) on the improvement of accessibility

6 A. Cieślik, B. Rokicki, Rola sieci transportowej w rozwoju polskich regionów: zastosowanie modelu potencjatu ekonomicznego, Acta Universitatis Niciolai Copernici. Economics 2013, 44(1), p. 113-127. 
caused by transport investments. This is particularly visible on the Polish-Ukrainian and Slovak-Ukrainian borders. The construction of new routes (including Via Carpatia) thus creates a hidden development potential that could be activated with the liberalization of border regimes. This confirms earlier theses regarding the mutual impact of the infrastructural barrier and the formal and legal barrier as the basic elements limiting the penetration of borders ${ }^{7}$.

\section{References}

Cieślik A., Rokicki B., Rola sieci transportowej w rozwoju polskich regionów: zastosowanie modelu potencjału ekonomicznego, Acta Universitatis Niciolai Copernici. Economics 2013, 44(1).

Gutiérrez J., Location, economic potential and daily accessibility: analysis of the accessibility impact of the high-speed line Madrid-Barcelona-French border, Journal of Transport Geography 2001, 9.

Komornicki T., Granice Polski. Analiza zmian przenikalności w latach 1990-1996, Geopolitical Studies 1999, 5.

Komornicki T., Spatial and social effects of infrastructural integration in the case of the Polish borders [in:] Linking networks: The formation of common standards and visions for infrastructure development, eds. M. Schiefelbusch, H.S. Dienel, Dorchester, Ashgate, 2014.

Rich D.C., Population potential, potential transportation cost and industrial location, Area, 1978.

Rosik P., Dostępność lądowa przestrzeni Polski w wymiarze europejskim, Prace Geograficzne 2012, 231.

Rykiel Z., Koncepcje granic w badaniach geograficznych, Geographical Review 1990, 62.

Spiekermann K., Wegener M., Květoň V., Marada M., Schürmann C., Biosca O., Ulied Segui A., Antikainen H., Kotavaara O., Rusanen J., Bielańska D., Fiorello D., Komornicki T., Rosik P., Stępniak M., TRACC Transport Accessibility at Regional/Local Scale and Patterns in Europe. Final Report, ESPON Applied Research 2014.

Stępniak M., Rosik P., Accessibility improvement, territorial cohesion and spillovers: a multidimensional evaluation of two motorway sections in Poland, Journal of Transport Geography 2013, 31.

Transport services and networks: territorial trends and basic supply of infrastructure for territorial cohesion. Final Report, ESPON 1.2.1, 2014.

\section{Corresponding authors}

Piotr Rosik can be contacted at: rosik@twarda.pan.pl

Tomasz Komornicki can be contacted at: t.komorn@twarda.pan.pl

Sławomir Goliszek can be contacted at: sgoliszek@twarda.pan.pl

Patryk Duma can be contacted at: p.duma@twarda.pan.pl

T. Komornicki, Granice Polski. Analiza zmian przenikalności w latach 1990-1996, Geopolitical Studies 1999, 5, p. 348; P. Rosik, Dostępność lądowa przestrzeni Polski w wymiarze europejskim, Prace Geograficzne 2012, 231, p. 310; T. Komornicki, Spatial and social effects of infrastructural integration in the case of the Polish borders [in:] Linking networks: The formation of common standards and visions for infrastructure development, eds. M. Schiefelbusch, H.P. Dienel, Dorchester Ashgate, 2014, p. 187-208. 